\title{
Changes in Human Red Blood Cells during Aging in vivo
}

\author{
Tatsuo Shinozuka \\ Department of Legal Medicine, School of Medicine, Keio University, Tokyo, Japan
}

(Received for publication on May 31, 1994)

\begin{abstract}
The human red blood cells survive in the circulation for 120 days. Density-gradient centrifugation technique is widely used to prepare red cell fractions of different ages. It has been known that various biochemical properties of the red cells change with aging in vivo. If the changes in the red cell surface lead to the destruction of senescent cells, it would be of interest to know how these changes are produced concerning the cell ages. Several different mechanisms for the both specific and nonspecific recognition have been considered. The first hypothesis concerning this mechanism demonstrated that desialylated glycophorins may play the role of recognition signal triggering the elimination of senescent red cells. There was also another hypothesis that demonstrated the red cell removal occurs due to the Fe receptor-dependent phagocytosis of the senescent cells by opsonization with anti-band 3 immunoglobulin $\mathbf{G}$ autoantibody. The present review provides a summary of the works in the area of red cell senescence. (Keio I Med 43 (3): 155-163, September 1994)
\end{abstract}

Key words: red blood cell, aging, senescence, aging mechanism

\section{Introduction}

It has been known that the life span of the human red blood cells in the blood stream is approximately 120 days. ${ }^{1}$ To clarify the aging mechanism of the red cells in vivo, biochemical characterization of the red cells of different ages has been investigated by numerous investigators. In particular, the relationship between the aging of the red cells and the intracellular components and/or the chemical composition of the red cell membranes were investigated. ${ }^{2-20}$

Today, the majority of the investigations concerning the red cell senescence is focused on the mechanism by which the aging of the cell promotes its destruction. The first hypothesis that the reduction in sialic acid induced a rapid sequestration of the red cells from circulation was proposed to explain the senescence and destruction of the red cells. ${ }^{4,21-26} \mathrm{~A}$ number of studies have provided the evidence that the IgG antibody that is bound to newly exposed sites on the membrane surface by desialylation would be effective in promoting macrophages' phagocytosis of the old red cells obtained from density separation method. ${ }^{26-29}$

Kay and coworkers ${ }^{30-34}$ proposed another hypothesis that one component of the aging process, namely a senescent antigen, might involve proteolytic cleavage of band 3 protein on the red cell membranes. ${ }^{31-33}$ They also mentioned that the old red cells appeared to have autologous serum antibodies bound to their surfaces. ${ }^{35,36}$

The present review is attempting to summarize the current biochemical researches on the changes and the destruction mechanism of the senescent red cells.

\section{Methods for Age-Correlative Separation of Red Blood Cells}

To clarify the age-associated changes of the red cells and the actual process of senescent cell destruction, many investigators have attempted to isolate the different population of the red cells. Density-gradient centrifugation has been a widely used method. ${ }^{28.29,37-42}$ The investigation with radioactive iron labeled cells revealed that the density of human red cells increased with aging. ${ }^{6,+3}$ This fact showed that the bottom layer of centrifuged cells (high-density cells) contained preponderantly old red cells, while young red cells were concentrated in the top layer of centrifuged cells (lowdensity cells). Piomelli and Seaman ${ }^{44}$ showed that the 
density separation, validated by much experimental evidence, remained a most useful technique for the study on the mechanism of red cell aging. Among the densityseparation techniques, a simple method which gave reasonably good separation was centrifugation at $30^{\circ} \mathrm{C}$, in an angle centrifuge at $39,000 \mathrm{Xg} .{ }^{37}$ The systems were devised for separating the red cells using the discontinuous gradient media of bovine serum albumin, ${ }^{38}$ arabino-galactane ${ }^{39}$ phthalate esters ${ }^{40}$ and polyvinylpyrrolidone-coated colloidal silica matrix (Percoll $\left.{ }^{\circledR}\right){ }^{28,29,41}$

Thompson et al ${ }^{45}$ adopted the counterflow centrifugation or elutriation technique, which separates the cells primarily on the basis of cell size. It was suggested that this technique provides some degree of age-dependent separation by using labeling studies in human subject. ${ }^{45,46}$

Marks and Johnson ${ }^{47}$ used a method by alternations in osmotic fragility. Differences in osmotic resistance between the young and the old red cells provided a basis for separating the whole cell populations into different age fractions.

The author reported a new approach to cell separation based on possible variations in surface charge. ${ }^{14}$ This method used the filtration of the red cells through alkylSepharose gels with various lengths of alkyl chains. Density-separated cell populations showed slightly different affinities for the octyl-Sepharose $6 \mathrm{MB}$ gel.

\section{Changes in Red Blood Cells during Aging in vivo}

\section{Morphological characterization}

The red cells obtained from fresh human blood were fractionated into three fractions, that is, top (lowdensity), middle and bottom (high-density) layers by the density gradient centrifugation. ${ }^{48}$ When compared with the top layer containing young red cells, the old red cells of the bottom layer showed decreases in mean corpuscular diameter (MCD), mean corpuscular surface area (MCSA) and mean corpuscular volume (MCV), but an increase in mean corpuscular average thickness (MCAT) as shown in Table 1.

The old cells isolated from normal human blood showed a marked reduction in their capacity to deform under shear stress. ${ }^{49,50}$ In addition to the contribution of increased intracellular viscosity, the old cells also appeared to have reduced surface area. ${ }^{49,50}$ It was thought that the deformability loss was mostly due to an increase in membrane rigidity. Whereas MCV decreased linearly with the red cell age, mean corpuscular hemoglobin concentration of the young red cells was lower than that of the lod red cells, which indicated that there was no loss of hemoglobin in the red cells during aging. 3,10

Nakao et al $^{51}$ described that the adenosin triphosphate (ATP) level in the red cells decreased gradually with their life-span in the blood vessels. They also suggested that the decrease of the ATP level caused the destruction

Table 1 Characteristics of Human Red Cells of Top (Young) and Bottom (Old) Laycrs Scparated by Density Gradient Centrifugation ${ }^{15.4 \times}$

\begin{tabular}{|c|c|c|c|}
\hline Fraction & $\begin{array}{c}\text { Top Layer } \\
(18.3 \pm 1.7 \%)\end{array}$ & $\begin{array}{l}\text { Bottom Layer } \\
(16.8 \pm 2.7 \%)\end{array}$ & $\begin{array}{c}\text { Relative } \\
\text { Percentage (\%) }\end{array}$ \\
\hline $\begin{array}{l}\text { Density } \\
(\mathrm{g} / \mathrm{ml})\end{array}$ & $<1.092$ & $>1.100$ & \\
\hline $\begin{array}{l}\mathrm{MCD} \\
(\mu \mathrm{m})\end{array}$ & $8.3 \pm 0.9$ & $7.2 \pm 1.7$ & 86.7 \\
\hline $\begin{array}{l}\text { MCAT } \\
(\mu \mathrm{m})\end{array}$ & $1.6 \pm 0.4$ & $1.8 \pm 0.3$ & 112.5 \\
\hline $\begin{array}{l}\text { MSCA } \\
\left(\mu \mathrm{m}^{2}\right)\end{array}$ & $134.5 \pm 20.6$ & $105.9 \pm 13.6$ & 78.7 \\
\hline $\begin{array}{l}\mathrm{MCV} \\
\left(\mu \mathrm{m}^{3}\right)\end{array}$ & $85.3 \pm 0.9$ & $71.8 \pm 0.6$ & 84.2 \\
\hline $\begin{array}{l}\text { ATP Lcvel } \\
\left(\mu \mathrm{mol} / 10^{\prime \prime \prime} \text { cells }\right)\end{array}$ & $0.81 \pm 0.09$ & $0.64 \pm 0.12$ & 79.0 \\
\hline $\begin{array}{l}\text { G-6-PDH Activity } \\
\text { (U/10 } 10^{11} \text { cells) }\end{array}$ & $1.90 \pm 0.25$ & $0.63 \pm 0.04$ & 33.2 \\
\hline $\begin{array}{l}\text { 2,3-DPG } \\
\text { ( } \mu \mathrm{mol} / \mathrm{ml} \text { cells })\end{array}$ & $5.74 \pm 0.82$ & $4.36 \pm 0.64$ & 76.3 \\
\hline $\begin{array}{l}\text { Sialic Acid } \\
\left(\mu \mathrm{g} / 10^{10} \text { cells }\right)\end{array}$ & $135.9 \pm 11.9$ & $109.9 \pm 5.7$ & 80.9 \\
\hline
\end{tabular}

"Rclative percentage was following equation: (Values of bottom layer red cells/Values of top layer red cells) $\times 100$. 
of the red cells in vivo. It was demonstrated that ATP levels in the old red cells were significantly lower than those in the young red cells (Table 1). Their study suggested that the viability of the red cells is not based on the shape but on the ATP level.

\section{Intracellular component}

Since hemoglobin constitutes the major mass of the red cells, it primarily determine their density. ${ }^{3,10}$ The cell density depends also on the water content of the red cell, which is regulated by the quantity of slowly permeable cytoplasmic constituents, primarily $\mathrm{K}$ and $\mathrm{Na}{ }^{13}$ The red cells with the higher-density are thought to represent the senescent population and contain less $\mathrm{K}$ and $\mathrm{Na}$ than the rest of cell populations. This nature of the red cells prompted the investigations of the transport pathways involved in regulation of intracellular $\mathrm{K}$ and $\mathrm{Na}$.

The ATP level, ${ }^{4,8.14,15}$ glucose-6-phosphate dehydrogenase (G-6-PDH) activity ${ }^{2,5,7,11,14,15}$ and 2,3-diphosphoglycerate (DPG) content $^{8}$ decreased in aged cells as shown in Table 1. It was also demonstrated that the activities of intracellular enzymes such as pyruvate kinase, ${ }^{6}$ cholinesterase, ${ }^{6,11}$ glutamate-oxaloacetate transaminase, ${ }^{2,9,10}$ and $\mathrm{Na} / \mathrm{K}$ ATPase ${ }^{9}$ were significantly lower in the old red cells than in young ones.

It was reported that glutathione of intercellular component decreased in aged cells. ${ }^{2}$ The old red cells showed moderately increased amounts of methemoglobin, which was accompanied by a decrease in cytochrome $b_{5}$ reductase and its cofactor, cytochrome $b_{5} .{ }^{12}$ The characterization of density-separated cells provided the evidence that the older cells suffered cumulative oxidative damage. ${ }^{52.53}$

\section{Membrane component}

The changes in the carbohydrate content of the human red cell membranes during the aging have been most widely investigated. ${ }^{5,6,11,15-18,20,42}$ Baxter and Beeley ${ }^{5}$ reported that the oldest cell fractions consistently showed a sialic acid content which was approximately by $15 \%$ lower than that of the cells at the top of the gradients (young). The study by Yaari $e t$ al ${ }^{+2}$ showed that there was significant difference in electrophoretic mobility between the young and the old red cells. The decrease of sialic acid content in the old cell population can be attributed to a reduction in membrane surface area of the red cells.

It was also reported that the other carbohydrate contents, such as neutral sugars and hexosamines, of the cell membranes were significantly higher in the young red cells than in the old ones. ${ }^{6,11,15-18.211}$ From these experimental results, it was presumed that the composition of membrane carbohydrates changed during cell aging of the human red cells, and that, either glycoprotein or glycolipid, or both types of complex carbohydrate changed.

Lutz and Fehr ${ }^{5.4}$ reported that the glycophorins extracted from the membranes of the young and the old human red cells had the same sialic acid content when referred to a relative measure of the number of glycophorins. They concluded that the human red cells lost intact glycophorin on the membranes during the red blood cell senescence.

Gattegno et al $l^{6}$ made a comparative study on the elution patterns in Sephadex G-25 gel filtration of membrane-surface sialoglycopeptides liberated from the young and the old human red cells with either pronase or trypsin. They reported that there were marked differences in the ratio of the sialic acid to neutral hexose of the main fractions of membrane-surface sialoglycopeptides. By authors' previous investigation, ${ }^{15}$ the amount of sialoglycopeptide mixture released from the young red cells by trypsin treatment was significantly higher than that from the old ones. The sialoglycopeptide from the young cells showed a greater proportion of sialic acid than that from the old ones. ${ }^{15}$

Cohen et $a l^{8}$ reported that both cholesterol and phospholipid phosphorus decreased similarly with the increasing cell density.

Kadlubowski ${ }^{19}$ demonstrated using SDS polyacrylamide gel electrophoresis that the aging in vivo of the red cells was virtually associated with significant alterations in the protein complement of the cell membrane.

\section{Blood-group activity and lectin receptor activity}

Since the blood group activity and lectin receptor activity of the red blood cells are attributed to the sugar residues in the terminal positions of the carbohydrate chains of glycolipids and/or glycoconjugates on their membranes, ${ }^{55}$ the relationship between the red cell aging and the changes in biological activities of the cells to various anti-sera and lectins were examined by several research groups. ${ }^{3,11,20,48,5(1)-60)}$

Greenwalt et $a l^{3.56}$ studied the relative agglutinability of the young and the old human red cells with the ABH, $\mathrm{I}, \mathrm{MN}$ and $\mathrm{Rh}$ reagents in an assay method by the continuous-flow autoanalyzer system. They found that the old red cells were more strongly agglutinated by $\mathrm{ABH}$ reagents than the young ones. The author ${ }^{(0)}$ examined the number and distribution density of $\mathrm{ABH}$ and $\mathrm{MN}$ antigen sites on the surfaces of the young and the old red cells using ${ }^{125}$ I-labeled blood group specific antibodies and lectins. It was found that increases in the distribution density of $\mathrm{A}_{1}, \mathrm{~B}, \mathrm{H}, \mathrm{M}, \mathrm{N}$ and Vicia graminea $\mathrm{N}$ antigen sites were observed in the old red cells compared with the young cells. From these results, it was presumed that $\mathrm{ABH}$ and $\mathrm{MN}$ antigens were not 
affected by enzymes including glycosidases and proteinases during the aging process in vivo.

Smalley and Tucker ${ }^{59}$ found, using immunoelectron microscopy with hemocyanin-conjugated antiglobulin, that the heterogeneity of the distribution density of blood group $A_{1}$ and $A_{2}$ antigen site was not age-related.

In the authors' study, ${ }^{48}$ compared with the young red cells, decreases in the number and distribution density of receptor sites for lectins including Limulus polyphemus (LPA), Canavalia ensiformis, Triticum vulgaris (WGA), Ricinus communis (II), Glycine max (soybean) and Bauhinia purpurea on the cell surfaces were observed in the old red cells as shown in Table 2. The number of WGA receptor sites on the cell surface was $2 \%$ lower in the old red cells than in the young ones, whereas the distribution density of WGA receptor sites on the cell surface was $27 \%$ higher in the old than in the young red cells (Table 2). On the basis of the invariability of the number of WGA receptor sites and the remarkable increased in the distribution density of the same receptor site during aging in vivo and considering the marked decrease in cell surface area found in the old red cells, it is probable that the human red cells shrink to reduce their surface areas without being vesiculated during aging in vivo. As LPA is a lectin which is capable of binding of sialic acid residues in glycoconjugates, ${ }^{61}$ the LPA receptors released from the red cell membranes were presumed to be certain sialic acid-containing glycoconjugates. It is inferred that the human red cell aging is accompanied by elimination of some glycoconjugates which have affinities for these lectins.

Choy et $a l^{11}$ reported as a result of examining the activities of the young and the old red cells against some lectins that a decrease of sialyl residue and an increase of galactosyl and $\mathrm{N}$-acetylgalactosaminoyl residues in the terminal position of the carbohydrate chains of membrane glycoconjugates are observed in old red cells. However, in the authors' study, both the young and the old red cells exhibited very weak binding activity for ${ }^{125}$ I-labeled PNA (Arachis hypogaea, peanut). ${ }^{48}$ Skutelsky et $a l^{58}$ found, from electron microscopic studies of the red cell membrane surfaces, that neither young nor old red cells reacted with ferritin-conjugated PNA. It is known that $\mathrm{MN}$ active sialoglycoproteins change into asialoglycoproteins, ${ }^{62,63}$ that is, Thomsen-Friedenreich (T) antigen which can be detected with PNA when sialic acid residues are removed from glycophorins by action of sialidase. ${ }^{58,64}$ From the authors' result ${ }^{48}$ and the observation by Skutelsky et al, ${ }^{58}$ it is implied that the human red cells are not exposed to sialidase during the aging in vivo.

\section{Survival of Senescent Red Blood Cells}

\section{Role of bound sialic acid on red blood cell membranes}

If the changes in the red cell surface lead to the destruction of senescent cells, it would be of interest to know how these changes are produced as the cell ages. Several possibilities were considered, and density-separated cells were examined for the evidence that such processes might have occurred (Table 3). Several different mechanisms including both specific and nonspecific for the recognition were summarized in Table 4 .

The old red cells were found to show a significant reduction in the total surface charge and in the sialic acid content. ${ }^{10,42}$ The first possibility to be proposed was that a loss of the highly negatively charged sialic acid residues

Table 2 Number and Distribution Density of Lectin Receptor Sites on Young and Old Human Red Cell Membranes ${ }^{48}$

\begin{tabular}{|c|c|c|c|c|c|c|c|c|}
\hline Population & & $\begin{array}{l}\text { Limulus } \\
\text { Polyphemus } \\
\text { (LPA) }\end{array}$ & $\begin{array}{c}\text { Canavalia } \\
\text { Ensiformis } \\
\text { (Con A) }\end{array}$ & $\begin{array}{l}\text { Triticum } \\
\text { Vulgaris } \\
\text { (WGA) }\end{array}$ & $\begin{array}{c}\text { Ricinus } \\
\text { Communis (II) } \\
\text { (RCA-II) }\end{array}$ & $\begin{array}{c}\text { Phaseolus } \\
\text { Vulgaris (E) } \\
\text { (PHA-E) }\end{array}$ & $\begin{array}{l}\text { Glycine Max } \\
\text { (SBA) }\end{array}$ & $\begin{array}{c}\text { Bauhinia } \\
\text { Purpurea } \\
\text { (BPA) }\end{array}$ \\
\hline $\begin{array}{l}\text { Young } \\
\text { Red Cells }\end{array}$ & $\begin{array}{l}\text { Number of receptor } \\
\text { site } \times 10^{6} / \text { cell }\end{array}$ & $0.76 \pm 0.09$ & $0.57 \pm 0.02$ & $4.10 \pm 0.59$ & $1.32 \pm 0.35$ & $0.57 \pm 0.10$ & $0.33 \pm 0.03$ & $0.47 \pm 0.03$ \\
\hline $\begin{array}{l}\text { Old } \\
\text { Red Cells }\end{array}$ & $\begin{array}{l}\text { Number of receptor } \\
\text { site } \times 10^{6} / \text { cell }\end{array}$ & $0.51 \pm 0.03$ & $0.35 \pm 0.04$ & $4.00 \pm 0.08$ & $0.93 \pm 0.39$ & $0.44 \pm 0.10$ & $0.18 \pm 0.02$ & $0.32 \pm 0.01$ \\
\hline $\begin{array}{l}\text { Pelative } \\
\text { Percentage }(\%)^{\text {a }}\end{array}$ & & 67 & 61 & 98 & 70 & 77 & 55 & 68 \\
\hline $\begin{array}{l}\text { Young } \\
\text { Red Cells }\end{array}$ & $\begin{array}{l}\text { Distribution } \\
\quad \text { density }\left(10^{4} \mu \mathrm{m}^{2}\right)^{\mathrm{b}}\end{array}$ & $0.57 \pm 0.06$ & $0.42 \pm 0.02$ & $3.00 \pm 0.46$ & $0.98 \pm 0.26$ & $0.42 \pm 0.08$ & $0.25 \pm 0.02$ & $0.35 \pm 0.02$ \\
\hline $\begin{array}{l}\text { Old } \\
\text { Red Cells }\end{array}$ & $\begin{array}{l}\text { Distribution } \\
\quad \text { density }\left(10^{4} \mu \mathrm{m}^{2}\right)\end{array}$ & $0.48 \pm 0.03$ & $0.33 \pm 0.04$ & $0.38 \pm 0.08$ & $0.88 \pm 0.37$ & $0.42 \pm 0.09$ & $0.17 \pm 0.02$ & $0.30 \pm 0.01$ \\
\hline $\begin{array}{l}\text { Relative } \\
\text { Percentage }(\%)^{\mathbf{c}}\end{array}$ & & 84 & 79 & 127 & 90 & 100 & 68 & 86 \\
\hline
\end{tabular}

Value represents mean \pm S.D. of ten experiments.

${ }^{a}$ Relative percentage was following equation: (Number of receptor sites of old red cells/Number of receptor sites of young red cells) $\times 100$.

${ }^{b}$ Distribution density was following equation: Number of receptor site/mean corpuscular surface area of cell membrane.

${ }^{\mathrm{c}}$ Relative percentage was following equation: (Distribution density of old red cells/Distribution density of young red cells) $\times 100$. 
Table 3 Summary of Reported Alterations in Aged Red Cells

\begin{tabular}{|c|c|}
\hline Alterations & References \\
\hline \multicolumn{2}{|l|}{ Morphological Characterization } \\
\hline Mean corpuscular diameter & 48 \\
\hline Mean corpuscular average thickness & 48 \\
\hline Mean corpuscular surface area & 48 \\
\hline Mean corpuscular volume & 10,48 \\
\hline \multicolumn{2}{|l|}{ Intracellular Component } \\
\hline Glucose-6-phosphate dehydrogenase (G-6-PDH) & $2,5,7,11,14,15$ \\
\hline Pyruvate kinase & 6 \\
\hline Cholinesterase & 6,11 \\
\hline Glutamate-oxaloacetate transaminase & $2,9,10$ \\
\hline $\mathrm{Na} / \mathrm{K}$ ATPase & 9 \\
\hline Cytochrome $b_{5}$ reductase & 12 \\
\hline Superoxide dismutase & 52 \\
\hline Glutathione peroxidase & 53 \\
\hline Glutathione reductase & 53 \\
\hline Glutathione & 2 \\
\hline $\mathrm{K}$ and $\mathrm{Na}$ & 13 \\
\hline Adenosin triphosphate (ATP) & $4,8,14,15$ \\
\hline 2,3-diphosphoglycerate (DPG) & 8 \\
\hline Hemoglobin & 3,10 \\
\hline \multicolumn{2}{|l|}{ Membrane Component } \\
\hline Total surface charge and sialic acid & 5,42 \\
\hline Carbohydrates & $6,11,15,16,17,18,20$ \\
\hline Cholesterol and phospholipid & 8 \\
\hline \multicolumn{2}{|l|}{ Blood-group Activity and Lectin Receptor Activity } \\
\hline Blood group activity & $3,20,56,59,60$ \\
\hline Lectin receptor activity & $11,48,57,58$ \\
\hline
\end{tabular}

Table 4 Signals Appearing on Red Cell Membrane

\begin{tabular}{lc}
\hline \hline Signal Suggested & References \\
\hline Desialylation of Sialoglycoprotein & $4,23,24,25,26$ \\
Exposure of Galactosyl Residues & $11,26,27,28,29,66$ \\
62 K Glycoprotein & 33,34 \\
Band 3 Protein Oligomers & 36 \\
IgG Antibodies Bind to Band 3 Protein & $30,31,32,33,34,35,36,72,73$ \\
\hline
\end{tabular}

from membrane glycoproteins reduced the repulsive interaction between the red cells and the phagocytes, thus permitting ingestion of the changed red cells. ${ }^{23-26}$ This hypothesis was suggested to a new concept of the role of carbohydrates in regulating the serum survival time of the plasma glycoproteins by Ashwell and Morell ${ }^{65}$ in 1974. They reported that a galactose was exposed as the terminal nonreducing sugar of protein-linked carbohydrate chains by treating the native protein with neuraminidase, and served as a specific determinant for the hepatic recognition of the sialic acid-deficient molecules (Fig 1(A)).

The study by Jancik et al ${ }^{23,24}$ was carried out to determine the physiological significance of sialyl residues to the viability of the red cells in the circulation. They reported that the release of bound sialic acid on the red cell membranes by neuraminidase treatment led to a significant reduction of the lifetime of these cells in circulation as shown in Fig 1(B). These experimental results led us to believe that the diminished surface charge may play a role in the removal of the senescent red cells from the circulation.

Choy et al ${ }^{11}$ suggested that the newly exposed galactose and galactosamine residues in the desialylated glycophorins may serve as recognition signals triggering the elimination of the senescent red cells from circulation. Alderman and coworkers ${ }^{28.29}$ concluded that age related antigenic determinants present on the senescent human red cells were exposed by desialylation of the major sialoglycoprotein component of the red cell membrane. 
(A)

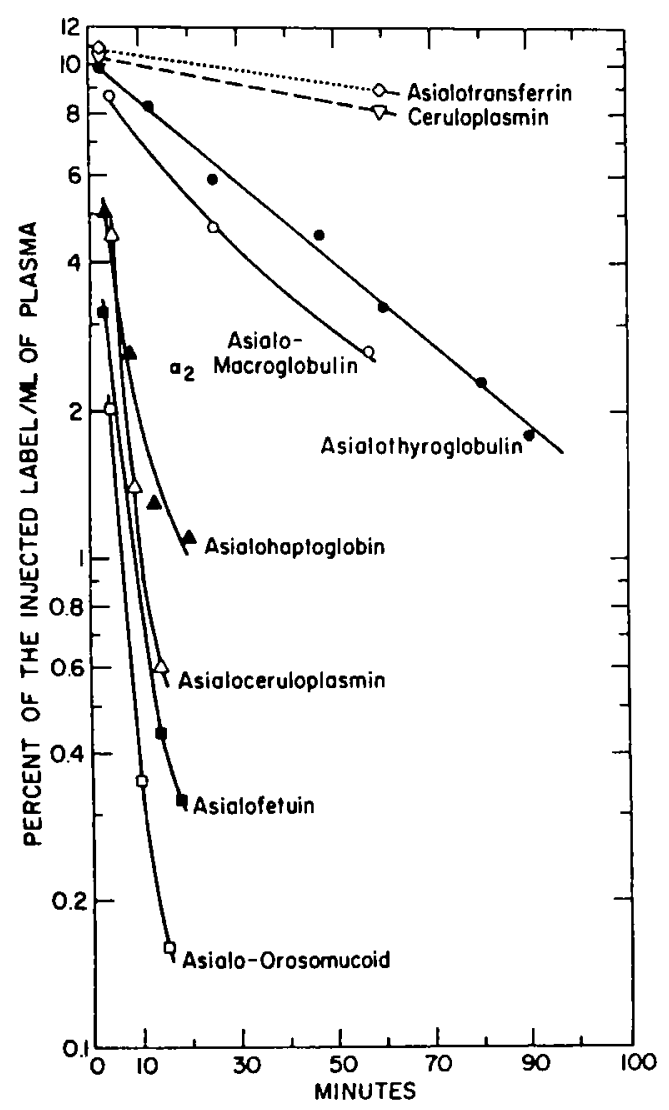

The study of Danon and Marikovsky ${ }^{27}$ suggested that the binding site for antibody on the senescent human red cells might have been the Thomsen-Friedenreich antigen, which was unmarked when sialic acid residues were removed from the membrane glycoprotein, and/or glycophorin.

There were many of the investigations ${ }^{6,15-18,20}$ saying that the old red cells decreased in contents of sialic acid accompanying with the various carbohydrates such as fucose, galactose, mannose, $\mathrm{N}$-acetylgalactosamine and $\mathrm{N}$-acetylglucosamine of the membranes. Lutz and Fehr ${ }^{54}$ reported that the glycophorins extracted from membranes of the young and the old red cells have the same sialic acid content. From these chemical findings, ${ }^{6,15-18,20}$ it seemed that the human red blood cell aging is accompanied by the elimination of some sialoglycoconjugates.

\section{Binding of autologous antibody on senescent red blood cell membranes}

The effect of sialic acid on the red cells survival were extensively studied. It was found that the reduction in sialic acid induced a rapid sequestration of the red cells from the circulation. This mechanism might have mean that the macrophage interact with the cytophylic
(B)

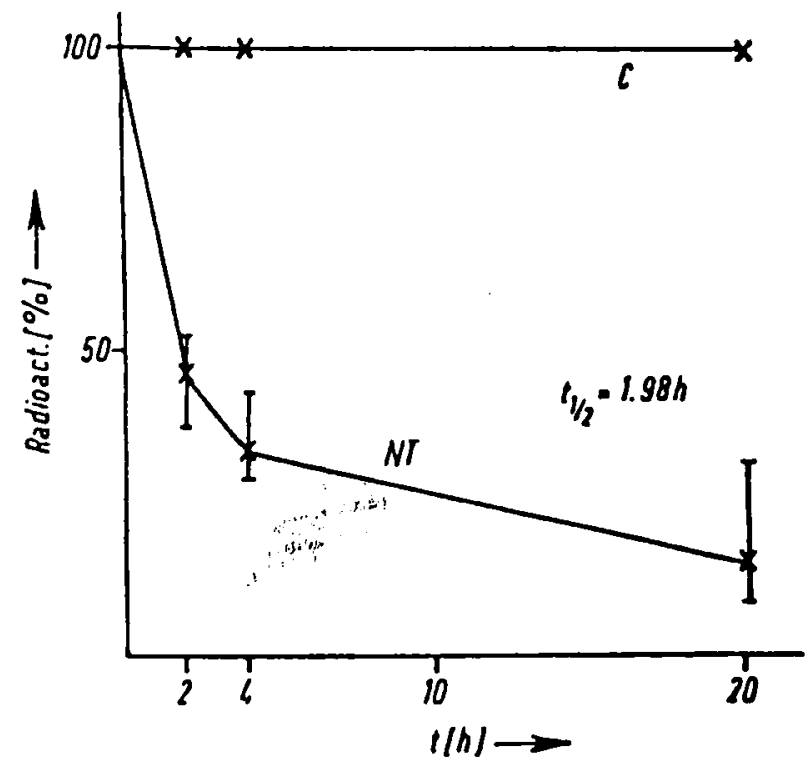

Fig 1 Plasma survival time of labeled asialoglycoproteins $(\mathrm{A}),{ }^{65}$ and radioactivity profiles in the whole blood after reinjection ${ }^{51} \mathrm{Cr}$ labeled human red blood cells (B) ${ }^{24} \mathrm{C}$ : control, NT: neuraminidase-treated red blood cells.

antibodies bound with the component of the newly exposed membrane sites by desialylation. Aminoff and his colleagues ${ }^{25,26.66}$ have suggested that the selective removal of sialic acid generated specific recognition sites that promoted phagocytosis. The results of their studies with human red cells suggested that the interaction between the old red cells and the liver macrophages leading to phagocytosis was able to be blocked by carbohydrates that had a $\beta$-galactosyl structure. The glycopeptide prepared from the old red cells by trypsin treatment had a terminal $\beta$-galactosyl residue that was absent in preparations from the young cells. It was proposed that the generation of the peptide on the surface of the aging red cell provided a signal that was recognized by a lectin-like receptor on macrophages, thereby promoting phagocytosis by an antibodyindependent mechanism.

Thus the surface recognition may provide the ultimate signal for cell destruction, but the appearance of the signal on the cell surface may be associated with a degradation of intercellular function. Other studies with rats provided firm evidence that desialylated red cells and high-density red cells were removed by different mechanisms. ${ }^{67}$ An extensive characterization of density-separated red cells failed to provide definitive evidence for a direct role for metabolic failure in the 
destruction of senescent cells.

En(a-) red cells lack the major sialoglycoprotein (glycophorin A) which carries the $\mathrm{MN}$ blood group determinants. ${ }^{68-71} \mathrm{En}(\mathrm{a}-)$ cells have less than one-half the normal sialic acid content, but there is no clinical abnormality. ${ }^{68}$ Tanner and Anstee ${ }^{68}$ reported that band 3 from En(a-) cells contained greater amounts of galactose and N-acetylglucosamine. Gahmberg et $a l^{69}$ reported that band 3 contained two oligosaccharides, and that the more complex oligosaccharide had a higher molecular weight in En(a-) cells than in normal cells. Lutz and Fehr ${ }^{54}$ reported that glycophorins A and B isolated from membranes of young and old red cells had the same sialic acid contents. These experimental results also indicated that the desialylated red cells and the old red cells were removed by different mechanisms.

Thus it was suggested that there existed a similar lectin-like receptor mechanism in human, and that there were observations by others implying an antibodydependent mechanism for phagocytosis of senescent human red cells. Kay et $a l^{30-34}$ reported that one of the mechanisms of the red cell removal was the $\mathrm{Fc}$ receptor-dependent phagocytosis of the senescent cells opsonized with anti-band 3 immunoglobin G (IgG) autoantibody. The senescent antigen to which antiband 3 IgG antibody binds on the cells is thought to be a 62000 -dalton fragment of band 3 molecules. ${ }^{33,34}$ Lutz et $a l^{35,36}$ suggested the binding of anti-band 3 IgG antibody to the red cells treated with diamide and the antigen to be the cross-linked band 3 molecules. Beppu et $a l^{72}$ had shown that anti-band 3 IgG antibody bound to the red cell oxidatively damaged by iron ion catalyst, and suggested involvement of disulfide formation of the membrane proteins in the generation of the senescent antigen. They also suggested that naturally occurring IgG autoantibody against band 3 glycoprotein of human red cell membranes recognized the red cells modified with oxidizing as well as the senescent red cells, and that the antigenic determinants of band 3 are located in sialylated poly- $\mathrm{N}$ acetyllactosaminyl sugar chains. ${ }^{73}$

Acknowledgements: The author wishes to express his gratitude to Professor Junichi Yanagida and Dr Naohito Kuroda, Department of Legal Medicine, School of Medicine, Keio University for their invaluable advice. The author is very grateful to Dr Seiichi Ohkuma, and Professor Hiroshi Watanabe, Department of Legal Medicine, The Saitama Medical School, for their invaluable discussions. This study was in part supported by the 1989-1990 Keio Gijuku Academic Development Funds and by the 1991 Grant-in-Aid from Keio Health Counseling Center, foundation Keio University Hospital Annex.

\section{References}

1. Harris JW, Kellermeyer RW eds: The Red Cell: Production,
Metabolism, Destruction: Normal and Abnormal, Cambridgc, Harvard Univ Press, 1974

2. Sass MD, Caruso CJ, O'Connell DJ: Decreased glutathione in aging red cclls. Clin Chim Acta 1965, 11: 3.34-340

3. Greenwalt TJ, Flory LL, Steane EA: Quantitative haemagglutination. III. Studics of separated populations of human red blood cells of different densities. Br J Hacmatol 1970, 19: $701-709$

4. Durocher JR, Paync RC, Conrad ME: Role of sialic acid in erythrocyte survival. Blood 1975, 45: 11-20

5. Baxter A, Bccley JG: Changes in surface carbohydrate of human erythrocytes aged in vivo. Biochem Soc Trans 1975, 3: 134-136

6. Gattegno L, Bladier D, Garnier M. Cornillot P: Changes in carbohydratc content of surface membranes of human erythrocytes during ageing. Carbohydr Res 1976, 52: 197-208

7. Walls R, Kumar KS, Hochstein P: Aging human crythrocytes Differential sensitivity of young and old crythrocytes to hemolysis induced by peroxide in the presence of thyroxine. Arch Biochem Biophys 1975, 174: 463-468

8. Cohen NS, Ekholm JE, Luthra MG, Hanahan DJ: Biochemical characterization of density-separated human erythrocytes. Biochim Biophys Acta 1976, 419: 229-242

9. Kadlubowski M, Agutter PS: Changes in the activities of some membranc-associated enzymes during in vivo ageing of the normal human crythrocyte. Br J Hacmatol 1977, 37: 111-125

10. Seaman GV, Knox RJ, Nordt FJ, Regan DH: Red cell aging. I. Surface charge density and sialic acid content of densityfractionated human erythrocytes. Blood 1977, 50: 1001-1011

11. Choy YM, Wong SL, Lee CY: Changes in surface carbohydrates of erythrocytes during in vivo aging. Biochem Biophys Res Commun 1979, 91: 410-415

12. Takeshita M, Tamura M, Yubisui T, Yoneyama Y: Exponential decay of cytochrome $b_{5}$ and cytochrome $b_{5}$ reductase during senescence of erythrocytes: relation to the increased methemoglobin content. J Biochem Tokyo 1983, 93: 931-934

13. Lec P, Kirk RG, Hoffman JF: Interrelations among $\mathrm{Na}$ and $\mathrm{K}$ content, cell volume, and buoyant density in human red blood cell populations. J Membr Biol 1984, 79: 119-126

14. Shinozuka T, Takei S, Watanabe H. Ohkuma S: Affinity of young and old human crythrocytes for alkyl-sepharose $6 \mathrm{MB}$ gels. J Chromatogr 1986, 375: 380-385

15. Shinozuka $T$, Takei S, Yanagida J, Watanabe H. Ohkuma S: Comparative study on the main membranc-surface sialoglycopeptides released from young and old human erythrocytes with trypsin. Comp Biochem Physiol B 1988, 89: 309-315

16. Balduini C, Balduini CL. Ascari E: Membrane glycopeptides from old and young human erythrocytes. Biochem J 1974, 140: $557-560$

17. Beeley JG, Blackic R. Baxter A: Glycoprotein and glycolipid changes in aged erythrocytes. Biochem Soc Trans 1977, 5: $1725-1726$

18. Bladier D, Gattegno L. Fabia F. Perret G, Cornillot P: Individual variations of the seven carbohydrate components of human erythrocyte membrane during aging in vivo. Carbohydr Res 1980 . 83: $371-376$

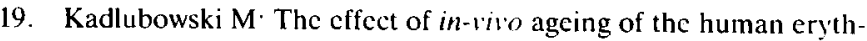
rocytc on the protein of the plasma membranc. A characterisation. Int J Biochcm 1978, 9: 67-78

20. Shinozuka T, Watanabe $H$, Takei S, Ohkuma S: ABO-MN antigenicitics and lectin receptor activities of old and young human erythrocytes. Nippon Hoigaku Zasshi (Jpn J Legal Med) 1984, 38: 397-402

21. Gattegno L, Bladier D, Cornillot P: The role of sialic acid in the determination of survival of rabbit crythrocytes in the circulation. Carbohydr Res 1974, 34: 361-369

22. Gattegno L. Bladier D. Cornillot P: Ageing in viro and ncurami- 
nidase treatment of rabbit erythrocytes: influence on half-life as assessed by ${ }^{51} \mathrm{Cr}$ labeling. Hoppe-Seyler's Z Physiol Chem 1975, 356: 391-397

23. Jancik J, Schauer R: Sialic acid - a determinant of the life-time of rabbit erythrocytes. Hoppe-Seyler's Z Physiol Chem 1974, 355: $395-400$

24. Jancik J, Schauer R, Streicher HJ: Influence of membrane-bound $\mathrm{N}$-acetylneuraminic acid on the survival of erythrocytes in man. Hoppe-Seyler's Z Physiol Chem 1975, 356: 1329-1331

25. Aminoff D, Bell WC, Fulton I, Ibgebrigtsen N: Effect of sialidase on the viability of erythrocytes in circulation. Am $\mathrm{J}$ Hematol 1976, 1: 419-432

26. Aminoff D, Bruegge WF, Bell WC, Sarpolis K, Williams R: Role of sialic acid in survival of erythrocytes in the circulation: interaction of neuraminidase-treated and untreated erythrocytes with spleen and liver at the cellular level. Proc Natl Acad Sci USA 1977, 74: 1521-1524

27. Danon D, Marikovsky $\mathrm{Y}$ : The aging of the red blood cell. A multifactor process. Blood Cells 1988, 14: 7-18

28. Alderman EM, Fudenberg HH, Lovins RE: Binding of immunoglobulin classes to subpopulations of human red blood cells separated by density-gradient centrifugation. Blood 1980, 55: $817-822$

29. Alderman EM, Fudenberg HH, Lovins RE: Isolation and characterization of an age-related antigen present on senescent human red blood cells. Blood 1981, 58: 341-349

30. Kay MM: Mechanism of removal of senescent cells by human macrophages in situ. Proc Natl Acad Sci USA 1975, 72: 3521-3525

31. Kay MM: Role of physiologic autoantibody in the removal of senescent human red cells. J Supramol Struct 1978, 9: 555-567

32. Kay MM, Goodman JR: IgG antibodies do not bind to band 3 in intact erythrocytes; enzymatic treatment of cells is required for IgG binding. Biomed Biochim Acta 1984, 43: 841-846

33. Kay MM, Goodman SR, Sorensen K, Whitfield CF, Wong P, Zaki L, Rudloff V: Senescent cell antigen is immunologically related to band 3. Proc Natl Acad Sci USA 1983, 80: 1631-1635

34. Kay MM: Localization of senescent cell antigen on band 3. Proc Natl Acad Sci USA 1984, 81: 5753-5757

35. Lutz HU, Bussolino F, Flepp R, Fasler S, Stammler P, Kazatchkine MD, Arese P: Naturally occurring anti-band-3 antibodies and complement together mediate phagocytosis of oxidatively stressed human erythrocytes. Proc Natl Acad Sci USA 1987, 84: 73687372

36. Lutz HU, Stringaro-Wipf G: Senescent red cell-bound IgG is attached to band 3 protein. Biomed Biochim Acta 1983, 42: S117-S121

37. Murphy JR: Influence of temperature and method of centrifugation on the separation of erythrocytes. J Lab Clin Med 1973, 82: $334-341$

38. Piomelli S, Lurinsky G, Wasserman LR: The mechanism of red cell aging. I. Relationship between cell age and specific gravity evaluated by ultracentrifugation in a discontinuous density gradient. J Lab Clin Med 1967, 69: 659-674

39. Piomelli S, Seàman C, Reibman J, Tytun A, Graziano J, Tabachnik $\mathrm{N}$, Corash L: Separation of younger red cells with improved survival in vivo: an approach to chronic transfusion therapy. Proc Natl Acad Sci USA 1978, 75: 3474-3478

40. Danon D, Marikovsky Y: Determination of density distribution of red cell population. J Lab Clin Med 1964, 64: 668-674

41. Rennie CM, Thompson S, Parker AC, Maddy A: Human erythrocyte fraction in "Percoll" density gradients. Clin Chim Acta 1979, 98: $119-125$

42. Yaari A: Mobility of human red blood cells of different age groups in an electric field. Blood 1969, 33: 159-163

43. Borun ER, Figueroa WG, Perry SM: The distribution of ${ }^{59} \mathrm{Fe}$ tagged human erythrocytes in centrifuged specimens as a function of cell age. J Clin Invest 1957, 36: 676-680

44. Piomelli S, Seaman C: Mechanism of red blood cell aging: relationship of cell density and cell age. Am J Hematol 1993, 42: 46-52

45. Thompson CB, Galli RL, Melaragno AJ, Valeri CR: A method for the separation of erythrocytes on the basis of size using counterflow centrifugation. Am J Hematol 1984, 17: 177-183

46. van der Vegt SG, Ruben AM, Werre JM, Palsma DM, Verhoef $\mathrm{CW}$, de Gier J, Staal GE: Counterflow centrifugation of red cell populations: a cell age related separation technique. Br J Haematol 1985, 61: 393-403

47. Marks PA, Johnson AB: Relationship between the age of human erythrocytes and their osmotic resistance: a basis for separating young and old erythrocytes. J Clin Invest 1958, 37: 1542-1548

48. Shinozuka $T$, Takei S, Yanagida J, Watanabe H, Ohkuma S: Binding of lectins to "young" and "old" human erythrocytes. Blut 1988, 57: 117-123

49. Nash GB, Meiselman HJ: Red cell and ghost viscoelasticity. Effects of hemoglobin concentration and in vivo aging. Biophys $\mathrm{J}$ 1983, 43: 63-73

50. Linderkamp O, Meiselman HJ: Geometric, osmotic, and membrane mechanical properties of density-separated human red cells. Blood 1982, 59: 1121-1127

51. Nakao K, Wada T, Kamiyama T, Nakao M, Nagano K: A direct relationship between adenosine triphosphate-level and in vivo viability of erythrocytes. Nature 1962, 194: 877-878

52. Glass GA, Gershon H, Gershon D: The effect of donor and cell age on several characteristics of rat erythrocytes. Exp Hematol 1983, 11: 987-995

53. Imanishi $H$, Nakai $T$, Abe $T$, Takino $T$ : Glutathione metabolism in red cell aging. Mech Ageing Dev 1985, 32: 57-62

54. Lutz HU, Fehr J: Total sialic acid content of glycophorins during senescence of human red blood cells. J Biol Chem 1979, 254: $11177-11180$

55. Gahmberg CG: Membrane glycoproteins and glycolipids: structure, localization and function of the carbohydrate. In: Finean JB, Michell RH, eds, Membrane Structure, Amsterdam, Elsevier, $1981,127-160$

56. Greenwalt TJ, Steane EA, Lau FO, Sweeney-Hammond K: Aging of the human erythrocytes. In: Sandler SG, Nusbacher J, Schanfield MS, eds, Immunobiology of the Erythrocytes, New York, A R Liss, 1980, 195-212

57. Marikovsky Y, Lotan R, Lis H, Sharon N, Danon D: Agglutination and labeling density of soybean agglutinin on young and old human red blood cells. Exp Cell Res 1976, 99: 453-456

58. Skutelsky E, Lotan R, Sharon N, Danon D: Distribution of the T-antigen on erythroid cell surfaces. Studies with peanut agglutinin, an anti-T specific lectin. Biochim Biophys Acta 1977, 467: $165-174$

59. Smalley CE, Tucker EM: Blood group A antigen site distribution and immunoglobulin binding in relation to red cell age. $\mathrm{Br} J$ Haematol 1983, 54: 209-219

60. Shinozuka T, Takei S, Yanagida J, Watanabe H, Ohkuma S: Number and distribution density of $\mathrm{ABH}$ and $\mathrm{MN}$ antigen sites on young and old human erythrocyte surfaces. Life Sci 1988, 43: $683-689$

61. Barondes SH, Nowak TP: Limulus polyphemus agglutinin (limulin). Methods Enzymol Relat Areas Mol Biol 1978, 50: 302-305

62. Bird GW, Wingham J: N-acetylneuraminic (sialic) acid and human blood group antigen structure. Vox Sang 1970, 18: 240-243

63. Uhlenbruck G: Erythrocyte mucoids. Vox Sang 1964, 9: 377-384

64. Lotan R, Sharon N: Peanut (Arachis hypogaea) agglutinin. Methods Enzymol Relat Areas Mol Biol 1978, 50: 361-367

65. Ashwell G, Morell AG: The role of surface carbohydrates in the hepatic recognition and transport of circulating glycoproteins. Adv Enzymol Relat Areas Mol Biol 1974, 41: 99-128 
66. Henrich $\mathrm{CJ}$, Aminoff $\mathrm{D}$ : Isolation and characterization of a glycopeptide from human senescent erythrocytes. Carbohydr Res 1983, 120: 55-66

67. Smedsrood B, Aminoff D: Studies on the sequestration of chemically and enzymatically modified erythrocytes. Am J Hematol 1983, 15: 123-133

68. Tanner MJ, Anstec DJ: The membrane change in En(a-) human erythrocytes. Absence of the major erythrocyte sialoglycoprotein. Biochem J 1976, 153: 271-277

69. Gahmberg CG, Myllyla G, Leikola J, Pirkola A, Nordling S: Absence of the major sialoglycoprotein in the membrane of human En(a-) erythrocytes and increased glycosylation of band 3 . J Biol Chem 1976, 251: 6108-6116

70. Shinozuka T, Miyata Y, Kuroda N, Takei S, Kurihara K, Yanagida
$\mathrm{J}$ : Serological and biochemical studies on En(a-) human erythrocytes in a Japanese family. Nippon Hoigaku Zasshi (Jpn J Legal Med) 1992, 46: 301-309

71. Shinozuka T, Miyata Y, Ohyama K, Takei S, Yamakawa T, Kurihara K, Yanagida J: Weak $N$ activity of En(a-) human erythrocyte membranes. Am J Hematol 1993, 44: 204-206

72. Beppu M, Mizukami A, Kikugawa K: Generation of senescent antigen on erythrocytes by partial blocking of SH groups of the membrane proteins. J Pharmacobiodyn 1992, 15: 353-358

73. Beppu M, Mizukami A, Ando K, Kikugawa K: Antigenic determinants of senescent antigen of human erythrocytes are located in sialylated carbohydrate chains of band 3 glycoprotein. J Biol Chem 1992, 267: 14691-14696 